\title{
Introducing the special issue
}

\section{'Advancement of insects as food and feed in a circular economy'}

\author{
A. van Huis ${ }^{*}$, B.A. Rumpold ${ }^{2}$, H.J. van der Fels-Klerx ${ }^{3}$ and J.K. Tomberlin ${ }^{4}$ \\ ${ }^{1}$ Laboratory of Entomology, Wageningen University E Research, P.O. Box 16, 6700 AA Wageningen, the Netherlands; \\ ${ }^{2}$ Department of Education for Sustainable Nutrition and Food Science, Technische Universität Berlin, Marchstr. 23, 10587 \\ Berlin, Germany; ${ }^{3}$ Wageningen Food Safety Research, Akkermaalsbos 2, 6708 WB Wageningen, the Netherlands; ${ }^{4}$ Department \\ of Entomology, Texas A\&M University, College Station, TX 77843-2475, USA; editor-in-chief@insectsasfoodandfeed.com
}

(C) 2021 Wageningen Academic Publishers

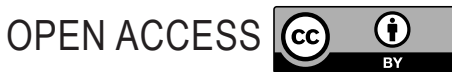

In 2017, a book was published entitled 'Insects as food and feed: from production to consumption' (Van Huis and Tomberlin, 2017). However, the sector of insects as food and feed is developing so quickly that an update seems appropriate. There has been an exponential increase in publications dealing with the topic. For example, using the words 'edible insect' as key words in 'Web of Science' scored 421 hits during the last two years (2019 \& 2020), an amount which equals the number recorded for the previous 20 years (1999-2018). We did consider publishing a new edition of the book, but concluded that the disadvantages outweighed the short-term results. We identified the following limitations: (1) it must be bought which limits its distribution; (2) the review process is less transparent and rigorous; and (3) the turnaround time for a book is much longer than for research articles. Thus, we felt that given the rate at which the industry is growing and diversifying, a second edition would possibly not be as up to date. In addition to the benefit of publishing up-to-date information quickly, we also concluded that the peer-review system would enhance its quality. Furthermore, publishing open access provides immediate engagement by parties globally in learning more about the industry or by enhancing their current facility. Fortunately, the authors and sponsors of such work were able to cover the open access costs.

As a means of transparency, it should be noted that the strategy adopted for assembling the topics and affiliated authors was done a priori. Authors with strong backgrounds on select topics were asked to contribute. Manuscripts were assigned to different Journal of Insects as Food and Feed editors, depending on their expertise. They were also charged with identifying reviewers as well as managing the review process. In some instances, editors were also authors or co-authors. However, they did not manage their own manuscripts in order to protect the integrity of the process.

All chapters dealt with relevant topics related to insects as food and feed, and most of the content of the articles is different from the 2017 book, reflecting developments in the field. In the description below, you will find the names of the authors who wrote the articles between parentheses.

So, the special issue starts with entotechnics, but instead of one chapter as in the 2017 book, four articles by the same author (Kok, 2021a,b,c,d), deal with the following topics: (1) overall mass and energy/heat balances; (2) organism kinetics, system dynamics and the role of modelling \& simulation; (3) sub-process types and reactors; and (4) facility consideration. Facility designs and processes to rear insects are covered from artisanal operations to world-scale plants. We hope this will help potential 'entopreneurs' to plan their process and their enterprise before making a major commitment and investment. Then the environmental impact of insect as food and feed is dealt with, in which lifecycle analysis studies were compared (Smetana et al., 2021). Increasingly the question is asked whether the industry can produce insects without compromising their welfare (Van Huis, 2021). When considering the environmental impact of insect mass production, the advantage of using insects as feed is the possibility to rear them on organic side streams. The question is what side streams can be used (Pinotti and Ottoboni, 2021). A topic that receives increasing attention is the role of microbes in transforming substrates into more acceptable materials for mass producing insects (Zhang et al., 2021). Manure is a major waste stream of particular concern in many of the countries which advocate a circular economy. What are the prospects of upcycling 
the manure using insects (Cammack et al., 2021)? A core issue with insect rearing and a major concern is colony health (Maciel-Vergara et al., 2021). While insects can be mass produced, manipulating their nutritional value is a key question (Oonincx and Finke, 2021). Furthermore, what is the role of genetics in improving the performance of mass produced insects (Eriksson and Picard, 2021)? What about left-over substrates? Can they be used as fertiliser and are there plant protecting effects (Chavez and Uchanski, 2021)? One of the major advantages of using edible insects is the possible health effects for humans (Stull, 2021) and animals (Gasco et al., 2021). Then, what is the effect of using insects as feed on the target animals: fish (Liland et al., 2021), poultry (Dörper et al., 2021), pigs (Veldkamp and Vernooij, 2021) and pets (Bosch and Swanson, 2021). Food safety deals with biological (Vandeweyer et al., 2021) and chemical (Meyer et al., 2021) contaminants. There is also the issue about allergies brought about by insect consumption (Ribeiro et al., 2021). These food and feed safety issues will have a direct effect on legislative issues and regulatory frameworks (Lähteenmäki-Uutela et al., 2021). The technique of processing is reviewed (Sinderman et al., 2021) as are processing pathways and the extraction and utilisation of insect proteins, lipids and chitins (Ojha et al., 2021). The final part of the special issue deals with consumer issues: how to design quality insect products (Reverberi, 2021) and how to convince consumers to buy insect products (Wassmann et al., 2021). The final question is whether the insect industry is profitable. There are not many publications on this issue but in one article the question is addressed (Niyonsaba et al., 2021). In the final chapter (Van Huis et al., 2021) we try to give some perspective of the future for the industry. While this view is clearly limited due to the industry still being in its infancy when compared to other food and feed sectors, the chapter potentially provides some guidance as to hurdles to be addressed, opportunities to be seized, and new questions to be formulated.

\section{References}

Bosch, G. and Swanson, K.S., 2021. Effect of using insects as feed on animals: pet dogs and cats. Journal of Insects as Food and Feed 7: 795-805. https://doi.org/10.3920/JIFF2020.0084

Cammack, J.A., Miranda, C.D., Jordan, H.R. and Tomberlin, J.K., 2021. Upcycling of manure with insects: current and future prospects. Journal of Insects as Food and Feed 7: 605-619. https:// doi.org/10.3920/JIFF2020.0093

Chavez, M. and Uchanski, M., 2021. Insect left-over substrate as plant fertiliser. Journal of Insects as Food and Feed 7: 683-694. https:// doi.org/10.3920/JIFF2020.0063

Dörper, A., Veldkamp, T. and Dicke, M., 2021. Use of black soldier fly and house fly in feed to promote sustainable poultry production. Journal of Insects as Food and Feed 7: 761-780. https://doi. org/10.3920/JIFF2020.0064
Eriksson, T. and Picard, C.J., 2021. Genetic and genomic selection in insects as food and feed. Journal of Insects as Food and Feed 7: 661-682. https://doi.org/10.3920/JIFF2020.0097

Gasco, L., Józefiak, A. and Henry, M., 2021. Beyond the protein concept: health aspects of using edible insects on animals. Journal of Insects as Food and Feed 7: 715-741. https://doi.org/10.3920/ JIFF2020.0077

Kok, R., 2021a. Preliminary project design for insect production: part 1 - overall mass and energy/heat balances. Journal of Insects as Food and Feed 7: 499-509. https://doi.org/10.3920/JIFF2020.0055

Kok, R., 2021b. Preliminary project design for insect production: part 2 - organism kinetics, system dynamics and the role of modelling \& simulation. Journal of Insects as Food and Feed 7: 511-523. https:// doi.org/10.3920/JIFF2020.0146

Kok, R., 2021c. Preliminary project design for insect production: part 3 - sub-process types and reactors. Journal of Insects as Food and Feed 7: 525-539. https://doi.org/10.3920/JIFF2020.0145

Kok, R., 2021d. Preliminary project design for insect production: part 4 - facility considerations. Journal of Insects as Food and Feed 7: 541-551. https://doi.org/10.3920/JIFF2020.0164

Lähteenmäki-Uutela, A., Marimuthu, S.B. and Meijer, N., 2021. Regulations on insects as food and feed: a global comparison. Journal of Insects as Food and Feed 7: 849-856. https://doi.org/10.3920/ JIFF2020.0066

Liland, N.S., Araujo, P., Xu, X.X., Lock, E.-J., Radhakrishnan, G., Prabhu, A.J.P. and Belghit, I., 2021. A meta-analysis on the nutritional value of insects in aquafeeds. Journal of Insects as Food and Feed 7: 743759. https://doi.org/10.3920/JIFF2020.0147

Maciel-Vergara, G., Jensen, A.B., Lecocq, A. and Eilenberg, J., 2021. Diseases in edible insect rearing systems. Journal of Insects as Food and Feed 7: 621-638. https://doi.org/10.3920/JIFF2021.0024 Meyer, A.M., Meijer, N., Hoek-Van den Hil, E.F. and Van der Fels-Klerx, H.J., 2021. Chemical food safety hazards of insects reared for food and feed. Journal of Insects as Food and Feed 7: 823-831. https:// doi.org/10.3920/JIFF2020.0085

Niyonsaba, H.H., Höhler, J., Kooistra, J., Van der Fels-Klerx, H.J. and Meuwissen, M.P.M., 2021. Profitability of insect farms. Journal of Insects as Food and Feed 7: 923-934. https://doi.org/10.3920/ JIFF2020.0087

Ojha, S., Bußler, S., Psarianos, M., Rossi, G. and Schlüter, O.K., 2021. Edible insect processing pathways and implementation of emerging technologies. Journal of Insects as Food and Feed 7: 877-900. https:// doi.org/10.3920/JIFF2020.0121

Oonincx, D.G.A.B. and Finke, M.D., 2021. Nutritional value of insects and ways to manipulate their composition. Journal of Insects as Food and Feed 7: 639-659. https://doi.org/10.3920/JIFF2020.0050

Pinotti, L. and Ottoboni, M., 2021. Substrate as insect feed for biomass production. Journal of Insects as Food and Feed 7: 585-596. https://doi.org/10.3920/JIFF2020.0110

Reverberi, M., 2021. The new packaged food products containing insects as an ingredient. Journal of Insects as Food and Feed 7: 901-908. https://doi.org/10.3920/JIFF2020.0111

Ribeiro, J.C., Sousa-Pinto, B., Fonseca, J., Fonseca, S.C. and Cunha, L.M., 2021. Edible insects and food safety: allergy. Journal of Insects as Food and Feed 7: 833-847. https://doi.org/10.3920/JIFF2020.0065 
Sindermann, D., Heidhues, J., Kirchner, S., Stadermann, N. and Kühl, A., 2021. Industrial processing technologies for insect larvae. Journal of Insects as Food and Feed 7: 857-875. https://doi.org/10.3920/ JIFF2020.0103

Smetana, S., Spykman, R. and Heinz, V., 2021. Environmental aspects of insect mass production. Journal of Insects as Food and Feed 7: 553-571. https://doi.org/10.3920/JIFF2020.0116

Stull, V.J., 2021. Impacts of insect consumption on human health. Journal of Insects as Food and Feed 7: 695-713. https://doi. org/10.3920/JIFF2020.0115

Van Huis, A., 2021. Welfare of farmed insects. Journal of Insects as Food and Feed 7: 573-584. https://doi.org/10.3920/JIFF2020.0061 Van Huis, A., Rumpold, B.A., Van der Fels-Klerx, H. and Tomberlin, J.K., 2021. Advancing edible insects as food and feed in a circular economy. Journal of Insects as Food and Feed 7: 935-948. https:// doi.org/10.3920/JIFF2021.x005
Van Huis, A. and Tomberlin, J., 2017. Insects as food and feed: from production to consumption. Wageningen Academic Publishers, Wageningen, the Netherlands, 448 pp. https://doi.org/10.3920/97890-8686-849-0

Vandeweyer, D., De Smet, J., Van Looveren, N. and Van Campenhout, L., 2021. Biological contaminants in insects as food and feed. Journal of Insects as Food and Feed 7: 807-822. https://doi.org/10.3920/ JIFF2020.0060

Veldkamp, T. and Vernooij, A.G., 2021. Use of insect products in pig diets. Journal of Insects as Food and Feed 7: 781-793. https://doi. org/10.3920/JIFF2020.0091

Wassmann, B., Siegrist, M. and Hartmann, C., 2021. Correlates of the willingness to consume insects: a meta-analysis. Journal of Insects as Food and Feed 7: 909-922. https://doi.org/10.3920/JIFF2020.0130 Zhang, J.B., Yu, Y.Q., Tomberlin, J.K., Cai, M.M., Zheng, L.Y. and Yu, Z.N., 2021. Organic side streams: using microbes to make substrates more fit for mass producing insects for use as feed. Journal of Insects as Food and Feed 7: 597-604. https://doi.org/10.3920/JIFF2020.0078 
